Научная статья

УДК 341.213

DOI https://doi.org/10.24866/VVSU/2073-3984/2021-3/117-131

\author{
А.П. Живец ${ }^{1}$ \\ С.Г. Верещагин ${ }^{2}$ \\ Владивостокский государственный университет экономики и сервиса \\ Владивосток. Россия
}

\title{
Федерализм и собственность (на примере американского федерализма)
}

\begin{abstract}
Рассмотрен механизм становления американского федерализма под углом борьбы интересов собственников. Поскольку на первых этапах существования США в части штатов юридически было закреплено рабовладение как один из видов собственности, а именно собственности на рабочую силу, то в конституционном и политическом процессах выражались, с одной стороны, борьба за сохранение рабства и его распространение, а с другой - попытки этому воспрепятствовать. В данной статье исследован период становления американского федерализма, освещается процесс создания государственных институтов. Проанализировано, с какой целью закреплялись и распределялись те или иные полномочия федерального правительства и штатов, каким образом они использовались в интересах различных категорий собственников, в том числе рабовладельцев. Посредством исторического и диалектического методов раскрываются сущность федерализма, его цели и задачи. При этом развитие явления государственно-правового характера рассматривается во взаимосвязи с экономическими, политическими факторами. Задача исторического и диалектического метода в данном случае показать, что содержание такого явления, как американский федерализм, определяется историей его развития, при этом сам американский федерализм непрерывно изменяется в результате противоборства различных факторов, сил, составляющих, тем не менее, единую социальную систему. В статье освещается тот факт, что различные отношения собственности пытались обрести и обретали политическую силу. Под собственностью понимаются не только
\end{abstract}

\footnotetext{
1 Живец Александр Павлович - аспирант, ассистент кафедры гражданско-правовых дисциплин; e-mail: AP.Zhivets@ vvsu.ru

2 Верещагин Сергей Григорьевич - канд. юрид. наук, д-р полит. наук, профессор; e-mail: sergey.vereshchagin@vvsu.ru
} 
уже сложившиеся отношения собственности, но и претензии и борьба за распределение различных благ в дальнейшем, в частности земли, в пользу тех или иных категорий населения. Конечно, в рамках данной статьи не освещен весь путь формирования американского федерализма, а только начальный. Но применение исторического метода подчеркивает, что он являлся ключевым для его развития. Значимость статьи состоит в том, чтобы определить алгоритм исследования развития государственно-правовых явлений и в других государствах, в частности, исследовать по этому принципу развитие федерализма в России.

Ключевые слова и словосочетания: федерализм, рабовладение, собственность, полномочия штатов, суверенитет, представительство, демократия, Конституция США.

\section{A.P. Zhivets}

\section{S.G. Vereshchagin}

Vladivostok State University of Economics and Service Vladivostok. Russia

\section{Federalism and property (on the example of American federalism)}

This paper examines the mechanism of the formation of American federalism from the angle of the struggle between the interests of owners. Since in the early stages of the existence of the United States, slavery was legally enshrined in some of the states as one of the types of property, namely the ownership of labor, the struggle for the preservation of slavery and its spread, on the one hand, and attempts to prevent it, on the other, were expressed in the constitutional and political process. This article examines the period of the formation of American federalism, highlights the process of creating state institutions. The article analyzes the purpose for which certain powers of the federal government and states were consolidated and distributed, how they were used in the interests of various categories of owners, including slave owners. Through the historical method and the dialectical method, the essence of federalism, its goals and objectives are revealed. At the same time, the development of a phenomenon of a state-legal nature is considered in conjunction with economic and political factors. The task of the historical and dialectical method in this case is to show that the content of such a phenomenon as American federalism is determined by the history of its development, while American federalism itself is constantly changing as a result of the confrontation of various factors and forces that nevertheless constitute a single social system. The article highlights the fact that various property relations have tried to gain and gained political strength. Property refers not only to the already established property relations, but also claims and the struggle for the distribution of various benefits in the future, in particular land, in favor of certain categories of the population. Of course, this article does not cover the entire path of the formation of American federalism, but only the initial one. But the application of the historical method emphasizes that it was key to its development. The significance of the article is to determine the algorithm for studying the development of state-legal phenomena in other states, in particular, to study the development of federalism in Russia according to this principle. 
Keywords: federalism, slavery, property, powers of states, sovereignty, representation, democracy, the US Constitution.

\section{Введение}

Соединенные Штаты Америки - одно из исторически первых федеративных государств. Наполнение содержания федерализма не было изначально раз и навсегда устоявшимся, оно было динамичным, изменялось в соответствии с изменением экономической ситуации, соотношением политических сил. При этом развитие американского федерализма не прекратилось.

Конечно, самоуправление местных общин в различных государственных и политических системах существовало во все времена. Тем более это характерно для государств с натуральным хозяйством и способом производства феодального или полуфеодального типа. Самоуправление существовало в крестьянских общинах, в городских коммунах, в древнерусских городах и в земствах Российского царства. Однако федерализм является свойством уже современных централизованных государств. Государства с различными степенями федерализма стали формироваться в период становления общегосударственной и глобальной торговли, развития мануфактурного, а затем и фабричного производства, то есть во время интенсивной индустриализации. Федерализм как система политических отношений есть определенное отражение этих экономических процессов. В конституционных актах федеративных государств или государств с элементами федерализма вопрос распределения полномочий по управлению собственностью и обеспечения единого экономического пространства был одним из ключевых.

Историческими предпосылками становления американского федерализма является колонизация североамериканского континента. Колонизация не планировалась государственной политикой, а проходила по большей части спонтанно, по факту выходцы из Англии (затем из Великобритании) самостоятельно заселяли атлантическое побережье Северной Америки. Одним из первых примеров создания самоуправления в колонии было самоуправление в колонии Массачусетс в соответствии с Мэйфлауэрским соглашением [1]. В дальнейшем структура и степень самоуправления менялись, происходило активное вмешательство королевской власти, но самоуправление оставалось.

Тем не менее, существовало три вида колоний: королевские (колония создавалась по королевскому указу), собственнические и корпоративные (колонизация организовывалась какой-то компанией). В образованных колониях создавались органы местного управления как на уровне небольших территорий, так и на уровне колоний. В их состав входили губернатор, который представлял короля, ассамблеи, верхняя палата ассамблеи - Колониальный Совет, члены которого назначались губернатором, и Палата Представителей, избираемая мужским населением колоний. Постепенно Палаты Представителей сосредоточили в своих руках колониальные финансы, бюджет, местное законодательство. От палат представителей колоний происходят современные законодательные собрания штатов. Конечно, по примеру метрополии была создана судебная система колоний.

В ходе войны за независимость возникла необходимость объединения колоний. Первым конституционным актом Соединенных Штатов, в котором был 
закреплён, в том числе, и принцип федерализма, были «Статьи Конфедерации и вечного союза». Несмотря на расплывчатость и рыхлость государственноправовой конструкции, отсутствие регламентации полномочий федерального правительства, этот документ фиксировал нерасторжимость союзных отношений между штатами, что уже характеризовало США как единое государственное образование. Хотя в статьях Конфедерации упоминалось, что штаты сохраняют суверенитет и независимость, фактически штатам были полностью запрещены внешние сношения с другими государствами (статья VI), заключение союзов между собой «иначе как с разрешения Соединенных Штатов», и только Соединенным Штатам было предоставлено решать вопросы войны и мира (статья IX) [2]. Таким образом, положение о том, что каждый штат сохраняет суверенитет, свободу и независимость, равно как и всякую власть, юрисдикцию и права, «которые особо не предоставлены этой конфедерацией Соединенным Штатам, собравшимся на конгресс», является остаточным анахронизмом. Тем не менее, «Статьи Конфедерации» не распределили должным образом полномочия между штатами и правительством Соединенных Штатов. Для этого было необходимо разработать новый конституционный акт, который впоследствии получил название Конституции Соединенных Штатов Америки. Особое внимание привлекает процесс разработки. Уже на этом этапе возникли конфликты между различными политическими группами, выражавшими интересы различных собственников. В нормах принятой Конституции были закреплены итоги попыток разрешить этот конфликт или хотя бы сгладить его проявление, достичь компромисса. Ocновной конфликт возник вокруг вопроса о рабстве.

Рабство, по сути, является неограниченной практикой использования другого человека в качестве рабочей силы, обеспечиваемой правом собственности рабовладельца на рабочую силу этого человека. Хотя практика работорговли и рабовладения в североамериканских колониях началась отчасти с инициатив предпринимателей метрополии, то есть Великобритании, а также молчаливого одобрения должностных лиц, которые назначались метрополией, никакого юридического закрепления рабства и работорговли в законодательстве Великобритании никогда не было. Традиции рабовладения собственно английское право, основными источниками которого были обычаи и прецеденты, не знало.

Иногда в метрополии случались судебные споры о «праве на раба», точнее о праве вывезти из Великобритании раба, которого до этого ввезли ранее. Чаще всего суды отказывались рассматривать такие споры, рекомендуя сторонам договориться миром, но некоторые дела дошли до рассмотрения уже судьей по настоянию истца. В этом процессе судья отказал в удовлетворении иска о вывозе раба, указав, что в Великобритании нет обычаев рабовладения, как таковое рабство может быть установлено только «позитивным правом» (то есть законодательством), которого в Великобритании также нет. Ввезенные из колоний в Великобританию рабы признавались свободными и защищались актом «Хабеас Корпус» [3].

Однако в североамериканских колониях, начиная с Вирджинии, постепенно, хоть и несистемно, начинается законодательное регулирование работорговли и 
статуса рабов. До принятия этих законодательных актов рабство, в частности, в этой колонии существовало лишь де-факто. Но именно для колоний характерно установление рабства «позитивным правом». Издание ассамблеями колоний законов, регулирующих рабство внутри колоний, признавалось также проявлением «самоуправления колоний», в которое метрополия не вмешивалась, поскольку рабство было зачастую основой экономики той или иной колонии. Но опять же не всех, а только тех, где было распространено плантационное хозяйство. В колониях севернее развивались промышленность и торговля промышленными товарами, мелкое фермерство, соответственно там рабовладение не имело экономической цели и места. При принятии Конституции США противоречие между этими типами хозяйствования станет одним из основных, что выразится в принятии определенных норм.

\section{Принятие Конституции США и последующая конституционно- правовая практика}

Итак, обратимся к конституционному процессу в период становления американского государства. Еще в июле 1776 года после принятия Декларации независимости делегаты в Континентальном конгрессе обсуждали, должны ли рабы для обеспечения создаваемого государства облагаться налогами в той же меpe, что и свободные люди. Предполагалось, что налогообложение должно было быть таким, чтобы сумма собранных в каждом штате налогов была пропорциональна численности населения штата. Нерабовладельческие штаты настаивали на том, что рабы должны вносить такой же вклад в экономику нового государства, что и свободные люди. Соответственно их численность должна учитываться при оценке налогообложения. Однако представитель Мэриленда С. Чейз возразил, что рабы являются ресурсом и негры-рабы не должны считаться членами штата. Будучи имуществом, они не могут отличаться от земли или от объектов собственности жителей тех штатов, в которых нет или мало рабов. По мнению Представителя Пенсильвании Дж. Уилсона, в южных штатах рабы должны облагаться налогом наравне со свободными людьми. В ответ были высказаны угрозы, что обсуждения подобного могут привести к распаду государства. Для рабовладельцев обложение рабов налогами означало изъятие части дохода, который они получали от эксплуатации рабов.

В итоге было принято решение в пользу рабовладельцев, и в соответствии со статьями Конфедерации рабы не считались при учете военнослужащих и лиц, облагаемых налогами [2].

Во время принятия Конституции ситуация изменилась. Когда принимались Статьи Конфедерации, каждый штат имел по одному голосу в Конгрессе, но теперь от численности населения штата зависело количество депутатов от штата в Палате Представителей США, а численность депутатов влияла на количество выборщиков от штата на выборах президента. Южане предложили, что в новой Конституции рабы должны быть признаны «людьми», но «другими людьми», для учета их численности в населении штата, что в дальнейшем обеспечивало закрепление за этими штатами определенного количества мест в Конгрессе. Другими словами, рабов предлагали считать субъектами политических прав 
наравне со свободными людьми. Напротив, противники рабства не хотели учитывать рабов для определения квоты (пропорции) представительства, поскольку в соответствии с законами южных штатов те считались объектами права собственности, а не людьми, обладающими правами, в том числе политическими, то есть рабы никогда не смогли бы голосовать или избираться в правительства штатов или федеральное правительство.

Более того, противники рабства понимали, что южане, получив дополнительные голоса в Конгрессе и в избирательной коллегии на основании численности рабов, могли использовать эти голоса лишь для дальнейшего закабаления рабов, упрочения и распространения системы рабовладения.

В итоге после споров в Конституции рабов все же обозначили как «людей», но при этом «других людей», в противоположность свободным людям. Термин «рабы» там никогда не упоминался, что стало уступкой южанам. Данная формулировка повторялась на протяжении всей Конституции. Например, пункт о работорговле формулировался так, что он отсылал к «таким людям», кого штаты решили принять под свою юрисдикцию (хотя формально термин работорговля там опять же не упоминается). Для регулирования вопроса о беглых рабах Конституция упоминает лица, «находящиеся на службе или на работе» в соответствии с законами штата.

Таким образом, Конституция использовала слово «люди», чтобы описать рабство, как если бы это были субъекты права, хотя на самом деле все в Конституционном конвенте понимали, что рабы на Юге считались имуществом, а не лицами, обладающими правосубъектностью. В итоге было одобрено правило при подсчете численности населения учитывать три пятых общего числа рабов, то есть в формулировке Конституции - «три пятых от общего числа "других людей"».

Представители Севера, будучи противниками закрепления за рабовладельцами преимуществ, конечно, понимали их реальный статус. Например, Представитель Нью-Джерси Патерсон возражал против этого компромисса, ссылаясь на то, что каждый знает, что к рабам (в рабовладельческих штатах) относятся «не иначе как к собственности». Тем не менее, все эти претензии не смогли помешать конвенту наделить рабовладение на Юге политической силой, назвав рабов «другими людьми» (в противоположность к свободным людям, являющимся избирателями). Таким образом, Конституционный конвент устанавливал представительство собственности, а не граждан [2].

Компромисс трех пятых утверждал, что представительство в Конгрессе будет основано на целом числе свободных людей и на трех пятых «от всех остальных». Но штаты самостоятельно своим законодательством устанавливали, кто свободный, а кто нет. Исходя из смысла Конституции невольничий статус создается законом штата - в конечном счете именно южные штаты получили возможность устанавливать, кто является рабом, а кто нет, навязывая свою волю федеральному правительству и «свободным» штатам (то есть тем штатам, где рабовладение было запрещено), влияя даже на федеральное налогообложение и миграцию.

В дебатах о налогообложении представители рабовладельческих штатов требовали конституционно запретить экспортные пошлины, поскольку южане 
опасались, что их используют как косвенный налог на рабов через обложение табака, риса и индиго, выращиваемых их рабами. Рабовладельцы настаивали на ограничении и точном перечислении полномочий федерального правительства, чтобы лишить его возможности в дальнейшем отменить рабство.

Казалось, что в Конституции полномочия между правительством и штатами распределялись таким образом, чтобы защищать интересы рабовладельцев.

Правда, в дальнейшем Конгресс принял Билль о Правах - 10 первых поправок к Конституции США. Десятая поправка гласила: «Полномочия, не делегированные Соединенным Штатам настоящей Конституцией и не запрещенные для отдельных штатов, сохраняются соответственно за штатами либо за народом».

Изначально эта поправка принималась как дополнительный инструмент, ограничивающий полномочия центрального правительства и защищающий рабство. Однако в ходе последующей государственно-правовой практики она была использована уже в пользу централизации, а затем и для отмены рабства. В самом деле, формулировка о том, что остаточные полномочия закреплены как за штатами, так и за народом, позволяла Конгрессу использовать эти полномочия как свои, поскольку именно Конгресс представляет народ. Тем более процедура принятия поправок к Конституции является реализацией права народа. Процедура принятия поправки предусматривает утверждение ее Конгрессом квалифицированным большинством голосов, а затем ее ратификацию тремя четвертями штатов (законодательными собраниями штатов) [3]. Штаты, которые не ратифицировали поправки, все равно обязаны подчиниться им и привести их в действие. Следует отметить, что Президент США не участвует в процессе принятия поправки, непосредственно реализуя свои полномочия. Поскольку Конгресс, по сути, утверждает предложение о вынесении поправки на ратификацию, она не является законодательным актом. Однако при принятии той же Тринадцатой поправки президент США влиял на процесс принятия через партийную систему.

Следует также остановиться на системе выборов Президента США. Выборы происходят косвенным образом. 6 сентября 1787 года Конгресс утвердил коллегию выборщиков. За конкретным штатом было зафиксировано определенное количество выборщиков, которые голосовали единым блоком от штата, а не пропорционально результатам общенационального голосования. Таким образом, фактически выборы президента проходят в каждом штате отдельно (пусть и одновременно), а голоса выборщиков от штата распределяются в пользу того кандидата, за которого проголосовало больше избирателей. Эта система называется «победитель получает все». Поскольку количество выборщиков от штата соотносилось с количеством делегатов в Палате Представителей Конгресса, то согласно принятому правилу учета трех пятых от «иных людей», то есть рабов, помимо собственно граждан, выходило, что и на выборах президента право голоса «предоставлялось» собственности [3].

Важным внутриполитическим событием, одним из поворотных пунктов становления американского федерализма в XIX веке оказался «Миссурийский компромисс». В результате развития государства и миграции населения на незаселенные территории на западе значительно возросло количество жителей 
территорий, от которых начали поступать петиции о приеме в США. В связи с этим неизбежно возникал вопрос о выборе статуса штата как рабовладельческого или свободного. При этом долгие годы в Сенате соблюдался равный баланс по количеству представителей от каждой стороны. В 1819 году петицию о вступлении в США подала федеральная территория Миссури, которая впоследствии и стала одноименным штатом. Одновременно штат Мэн декларировал свое образование в составе США и подал петицию на его утверждение, при этом штат Мэн был образован из части территории штата Массачусетс.

Начало дебатов по вопросу принятия Миссури в состав США неразрывно связано с именем нью-йоркского конгрессмена Дж. Толмэджа. 13 февраля 1819 г. он предложил поправку к законопроекту о принятии нового штата Миссури, согласно которой обязательными условиями вступления в США были полный запрет на ввоз рабов и последующее освобождение детей уже имевшихся невольников, рожденных после обретения территорией Миссури статуса штата. План Толмэджа не освобождал уже ввезенных рабов, но он предусматривал постепенную и, соответственно, мирную ликвидацию рабства в Миссури. После этого предложения в Палате Представителей начались дискуссии. На принятии поправки настаивали преимущественно представители Севера. Дж. Тейлор из Нью-Йорка сформулировал два ключевых вопроса: «Обладает ли Конгресс полномочиями требовать от Миссури конституционного запрета на дальнейшее распространение рабства в качестве условия вступления в США?» и «Если такое право существует, то разумно ли использовать его?» [5; 6]. На оба эти вопроса он давал утвердительный ответ, обосновывая их широким толкованием Конституции специальным актом Конгресса от 1787 г., известным как Северо-западный ордонанс, и общепризнанными моральными нормами. Т. Фуллер из Массачусетса считал, что данный институт мешает установить «подлинно республиканское правительство» в Миссури, а поправка поможет достичь этой цели. Кроме того, он указал на явное противоречие принципов, изложенных в Декларации независимости, и практики рабовладения.

Инициатор поправки Толмэдж в обращении к Конгрессу настаивал на искоренении рабства любыми средствами. Причем он говорил о возможности распада США и гражданской войны, если она будет необходима. Кроме того, он отметил распространение рабовладения на новые территории. Также он затронул правило представительства трех пятых от числа рабов, которые обеспечивали Югу дополнительные места в Конгрессе, без которых, учитывая стремительный рост населения свободных штатов, регион быстро лишился бы влияния.

Разумеется, были высказаны возражения против поправки. В частности, прозвучали такие возражения, что рабство не может противоречить Конституции, поскольку при ее принятии в состав США уже входили штаты, в которых существовало рабство. В конечном счете, предложение Толмэджа было одобрено Палатой Представителей в качестве поправки к биллю о принятии Миссури, но отклонено Сенатом и возвращено в Палату Представителей в первоначальном виде. В результате Миссурийский билль был вообще снят с рассмотрения в 1819 году [6]. Позже Сенат, рассматривая билль о принятии Миссури, объеди- 
нил его вместе с биллем о принятии штата Мэн и принял их как единый акт, конечно, без предложения о запрете рабства в штате Миссури. Теперь уже Палата Представителей была против. (Законодательный процесс в США устроен таким образом, что любая из палат может инициировать и принять закон, чтобы затем он был одобрен другой палатой, после чего он становится принятым Конгрессом.)

В итоге после продолжительных дискуссий и споров Конгрессом было принято компромиссное решение, согласно которому в состав США вошли штаты Мэн и Миссури посредством принятия единого акта, штату Миссури позволялось легализовать рабовладение, в новообразованном штате Мэн оно запрещалось. Кроме того, рабство запрещалось во всех штатах (включая будущие) севернее 36 градуса северной широты.

Принятие Миссурийского компромисса свидетельствовало о том, что Конгресс, несмотря на наличие полномочий, предусмотренных десятой поправкой, в принципе не может ими в данный момент воспользоваться и запретить рабовладение на всех новых территориях, входящих в США в качестве штатов, включая Миссури.

Если бы была принята поправка Толмэджа, а штат Миссури все равно в своей Конституции узаконил бы рабство, то это было бы самым радикальным воплощением «прав штатов», на которых настаивали рабовладельцы.

Пришлось бы навязывать волю силой, однако политические силы в тот момент не были готовы к гражданской войне, тем более представленные в Конгрессе и Правительстве. Также обнаружилось, что отсутствие партийной системы (на тот момент она еще не была сформирована в США) составляет значительное неудобство. Эти события в Конгрессе вынудили создавать партии [6].

Миссурийский компромисс действовал достаточно долго, но уже в 1850 году произошло отступление от него. Калифорния была принята как штат, в котором рабство запрещалось, но взамен вводились нормы о поимке и выдаче беглых рабов с территорий «свободных» штатов.

Уже затем произошли события, полностью уничтожившие Миссурийский компромисс. Фактически обозначилось, что две системы (рабовладельческая и противоположная ей) в одном государстве уже существовать не могут. Причем на первый взгляд казалось, что есть тенденция к установлению на территории США именно системы плантационного рабовладения и политические силы не смогут этому помешать через государственные институты.

В 1854 году Конгресс США принял так называемый Акт «Канзас-Небраска» [7], в котором был кардинально пересмотрен ранее принятый Миссурийский компромисс. Теперь население заселяемых территорий, в дальнейшем принимаемых в состав США как штаты, решало по собственному усмотрению вопрос легализации рабовладения (Канзас стал штатом в составе США в 1861 году уже во время Гражданской войны, а Небраска после Гражданской войны в 1865 году). Это разрушало хрупкий баланс двух сил. Принятие Конгрессом «Акта Канзас-Небраска» обосновывалось так называемым «священным правом самоуправления», «поселенческим суверенитетом». Этот закон мог стать инструментом распространения рабства, но в тот момент он спровоцировал в Канзасе малую 
гражданскую войну - «Кровавый Канзас»- между свободными фермерами, нуждающимися в земле для фермерства, и рабовладельцами, которым нужна была земля для плантаций, на которой трудились бы рабы. После этой малой гражданской войны в Конституции Канзаса в 1859 году рабство было запрещено.

Следует отметить следующий факт: с распространением рабовладения на западные территории рабовладельцы присваивали себе все большее количество земель или имели такое намерение. С другой стороны, на Севере было большое количество людей, нуждающихся в земле на западе, чтобы заниматься фермерством. Другими словами, проблема распространения рабства касалась не только распространения собственности на рабочую силу, но и распределения новых земель, получения земли в собственность и ее использования. Сама Республиканская партия была образована как раз на базе Партий фермеров, в программе которых заявлялся запрет на распространение рабства на новые территории и предоставление земельных участков освоенных территорий фермерам.

Позже почти одновременно с этими событиями в 1856 году Верховный суд США рассматривал дело «Дред Скотт против Сэнфорда». Вкратце обстоятельства данного дела таковы: Дред Скотт, раб Джона Эмерсона, приехал вместе с ним из рабовладельческого штата Миссури в штат Иллинойс, в котором рабство было запрещено сначала в Конституции штата, а затем на федеральном уровне согласно упомянутому выше Миссурийскому компромиссу. Затем Дред Скотт вернулся вместе с женой Эмерсона в штат Миссури. После смерти Эмерсона в 1842 году Дред Скотт стал рабом его вдовы в порядке наследования. Скотт предлагал ей выкупиться, однако она не согласилась, тогда Скотт обратился в суды, в конечном итоге, дело дошло до Верховного суда США. Скотт требовал своего освобождения, мотивируя тем, что был перевезен в штат, где рабство было запрещено, а значит, это делало его свободным [8; 9]. Верховный суд США, рассмотрев дело, постановил следующее: Дред Скотт является «имуществом», не является гражданином США и, соответственно, не имеет правоспособности, чтобы подавать иски в суды США (интересно, что из этого положения следовало, что подавать иски в суды США могут только граждане США, а иностранцы или лица без гражданства, пусть и свободные, не могут).

Кроме того, Верховный суд США пошел дальше. Во-первых, большинство судей, в том числе Председатель Верховного суда судья Роджер Тэни, утверждают, что афроамериканцы, даже если они не являются рабами, в принципе не могут быть гражданами США и никогда не могли бы создать политическое сообщество вместе с людьми «белой расы».

Во-вторых, утверждалось, что федеральное правительство или Конгресс не могут законодательным актом запрещать рабство на каких-либо территориях, в какихлибо штатах, этот вопрос относится к прерогативам штата, не могут устанавливать статус личностей на территории штата, это также относится к прерогативам штата.

Таким образом, Верховный суд США просто аннулировал Миссурийский компромисс как противоречащий Конституции, таким образом, для штатов, в которых на тот момент рабство было запрещено согласно этому компромиссу, данный 
запрет признали недействительным. Однозначным лишь оставался запрет в тех штатах, которые входили в США на момент принятия Конституции [8; 9].

Безусловно, Верховный суд США имеет право толковать Конституцию США, однако судьи Верховного суда США, в частности его председатель Роджер Тэни, не столько заботились об обосновании своего решения Конституцией США, сколько продвигали свою политическую позицию и идеологию, защищали определенные интересы.

Судьи, не согласившиеся с большинством, отмечали, что, во-первых, еще на момент принятия Конституции США многие свободные афроамериканцы участвовали в выборах, тем самым направляя делегатов в Конституционный конвент, избирали депутатов законодательных собраний штатов и так далее, то есть являлись гражданами. Иначе говоря, это расистское положение в решении Верховного суда США просто расходилось с действительностью. Во-вторых, эти судьи указывали, что не могут найти в Конституции США положение, которое ограничивает Конгресс в издании законов, запрещающих рабство на конкретных территориях. Тем не менее, эти судьи оказались в меньшинстве. Решения Верховного суда США оспорить негде, пересмотреть эту позицию мог бы только другой состав.

Данное решение полностью разрушило баланс сил в США, причем если акт «Канзас-Небраска» отменял Миссурийский компромисс для будущих территорий, штатов, то решение Верховного суда США прекратило его действия и для уже принятых. Это еще раз показало невозможность сосуществования в США двух систем собственности, производства и распределения благ, при этом оставался только силовой путь решения проблемы. Сецессия ряда южных штатов и гражданская война в США и стали этим путем. В период войны Конгресс принимает Акт о гомстеде, согласно которому свободные фермеры могли получить в собственность земельные участки на заселяемых территориях на западе [10]. В 1863 году Линкольн издает Прокламацию об отмене рабства, применяемую в мятежных штатах. Линкольн указывал, что это, по сути, конфискация имущества у мятежников. В 1865 году уже после фактической победы в гражданской войне Конгресс наконец принимает Тринадцатую поправку к Конституции США, которая запрещает рабство. Необходимое число штатов ее ратифицирует. Конечно, Верховный суд США уже не может признать неконституционной поправку к Конституции. В дальнейшем не будет попыток оспорить полномочия Конгресса издавать законодательные акты, вмешивающиеся в дела штатов.

Перед президентскими выборами 1860 года часть штатов заявили о своем отделении, провозгласили создание Конфедеративных штатов Америки. Инициативы федерального правительства по проведению диалога с отделившимися штатами для восстановления единства государства были аннулированы военной акцией со стороны отделившихся штатов (обстрел форта Самтер). В ответ федеральное правительство объявило отделившиеся штаты в состоянии мятежа, началась гражданская война.

После гражданской войны США прошли через этап Реконструкции Юга с характерным для него военным управлением бывшими мятежными территориями, 
восстановлением гражданского самоуправления, а затем межпартийных компромиссов, уступок местным элитам в возможности проводить фактически дискриминационную политику (в частности, ограничивать избирательные права) на местном уровне в обмен на доминирование и возможности проведения политики Республиканской партии на федеральном. Федеральный законодатель просто устранился от вмешательства в эти вопросы.

Дискриминационное законодательство в южных штатах будет ликвидировано только спустя несколько десятилетий, этот процесс закончится в 60-х годах $\mathrm{XX}$ века.

Однако каково же было политическое обоснование сецессии части южных рабовладельческих штатов?

Анализ деклараций о сецессии показывает: южане четко осознавали и безапелляционно заявляли, что раскол США происходит из-за института рабства, который они стремятся сохранить, в то время как Север желает его постепенного уничтожения. Характерно, что, когда началась сецессия, в специальном «Обращении конвента граждан штата Южная Каролина к жителям рабовладельческих штатов США», принятом 25 декабря 1860 г. и написанном ярым сторонником отделения журналистом Р. Реттом, говорилось, что федеральная Конституция 1787 г. была создана в целях защиты рабовладения и не предполагала его отмены, а северные штаты посягают на конституционно одобренные институты.

Была ли сецессия конституционной? Во-первых, сецессионисты не столько заботились о соответствии их действий Конституции США, сколько ставили конкретную цель. Просто выхода из США им было недостаточно. Объявившие о выходе рабовладельческие штаты пытались также насильственным путем присоединить к себе рабовладельческие штаты, объявившие о лояльности США. Кроме того, уже не связанные Конституцией США и будущими актами Конгресса, они стремились распространить рабовладение на новые территории [11]. Акт сецессии был реакцией на перспективу преобладания в Конгрессе США Республиканской партии и победы ее представителя на президентских выборах - Авраама Линкольна.

Ответ на вопрос о правомерности выхода штатов из США с точки зрения Конституции США дал Верховный суд США уже после гражданской войны в деле «Техас против Уайта» [12; 13].

Председатель Верховного суда США Салмон Чейз написал, что изначально Соединенные Штаты были созданы в ответ на реальные проблемы, с которыми столкнулись колонисты. Первым результатом этих обстоятельств явилось создание Статей Конфедерации, которые создали вечный союз между штатами, принимавшими участие в создании. Принятая позже Конституция лишь укрепила и усовершенствовала эти вечные отношения. Чейз написал: «Союз штатов никогда не был абсолютно искусственными и случайными отномениями. Он начал создаваться между колониями и вырос из общего происхождения, взаимных симпатий, родственных принципов, схожих интересов и географических отношений. Он был подтверждён и усилен необходимостью сражаться, получил определённую форму, характер и одобрение с созданием Статей Конфедерачии. 
Статьи торжественно провозгласили союз «бессрочным». Когда статьи перестали удовлетворять потребностям страны, была создана Конституция, предписанная «для создания более совершенного Союза». Трудно передать идею о неразрывном единстве яснее, чем этими словами. Что может быть более неразрывным, если не вечный союз, ставший более совершенным?».

\section{Заключение}

Итак, в литературе неоднократно поднимался вопрос о сути федерализма и федерации и их назначении. Часто предлагались определения федерализма или федеративных государств как государств, в которых территориальные единицы обладают частичным суверенитетом или, иначе говоря, суверенитет разделен. Такие определения встречаются и в современной литературе.

Государственно-политическая и правовая практика, в частности история государственно-правовых отношений в США, показывает, что в федеративном государстве не может быть двух уровней суверенитета. Его в принципе не может быть. Согласно распространённому в теории государства и права определению суверенитет - это такое свойство государственной власти, которое выражается в верховенстве ее внутри страны (отсутствии подчиненности ее кому-либо в системе) и независимости ее вовне, а также международной правосубъектности.

Мы не будем сводить все только к умозрительному толкованию определений. Практика показывает, что любая попытка субъектов федерации к суверенизации либо приводила к распаду государства, либо эффективно подавлялась государством в целом.

Авраам Линкольн говорил, что государство не может и не должно в своей конституции содержать положения, позволяющие какой-либо части выйти из него, то есть содержать положения о самоуничтожении.

Первый этап развития американского федерализма характеризуется следующим. В этот период происходила борьба между политической группой собственников-рабовладельцев из рабовладельческих штатов, с одной стороны, и группами свободных фермеров и капиталистов-собственников различных заводов и иных предприятий из свободных штатов - с другой. В ходе этой борьбы рабовладельцы не столько отстаивали так называемые права штатов перед правами (полномочиями) федерального правительства, сколько пытались установить такие права (полномочия) штатов, которые охраняли бы их рабовладельческую собственность или применялись бы в целях защиты, а также федеральные полномочия в тех же целях и для присвоения земли и распространения рабства. Напротив, права (полномочия) как штатов, так и федерального правительства, которые не служили бы, а противоречили их интересам, они оспаривали или пытались воспрепятствовать их реализации (например, обязательства «свободных» штатов предпринимать меры по поиску и выдаче беглых рабов, причем в упрощенном порядке эта норма была введена в 1850 году). Для своих целей они пытались установить недемократические (антидемократические) институты в виде конкретных норм, внедряли антидемократические практики. В конечном счете они развязали гражданскую войну, в ходе которой стремились не столько к независимости, сколько к тому, чтобы поставить под свой контроль большую 
часть США и перестроить государство в своих целях, распространив рабовладение на новые территории, закрепив не только право собственности на рабов конституционно, но и возможность установить его где угодно. Соответственно нуждающиеся в земле фермеры были бы ущемлены [11].

Эта государственно-правовая практика показала, что федерализм является не самоцелью, а инструментом, который можно использовать в интересах разных групп. Кроме того, данная практика продемонстрировала, что защита прав собственности, а точнее прав конкретных собственников может осуществляться явно недемократическими, даже антидемократическими средствами. В конечном счете, собственники для защиты своих прав стремятся уничтожить демократию как таковую.

1. Слёзкин Л. Ю. Соглашение на «Мэйфлауэре».- Текст: электронный // VIVOS VOCO! - 3ОВУ $\quad$ жИВЫХ!: [сайт]. - URL: http://vivovoco.astronet.ru/vv/papers/history/flower.htm(дата обращения: 7.06.2021).

2. Introduction - Articles of Confederation: Primary Documents in American History Текст электронный // Research Guides at Library of Congress [сайт]. - URL: https://guides.loc.gov/articles-of-confederation (дата обращения: 7.06.2021).

3. Финкельман П. Как американский закон и Конституция США определяли рабство / пер. с англ. К. Сарычевой; под ред. Н. Поселягина // Новое литературное обозрение. - 2016. - Вып. 6. - С. 213-248

4. US Constitution - Full Constitution of The United States [сайт]- URL: https://constitutionus.com (дата обращения: 7.06.2021).

5. Исаев С. А. Миссурийский компромисс, 1819-1821 // Американский ежегодник. 2007. - Вып. 2005. - С. 72-89.

6. Нечай С. Л. Президент Монро и споры о рабстве в конгрессе США в 1819-1821 годах // Всеобщая история: современные исследования: сб. науч. тр. - Брянск, 2013. C. $74-88$.

7. Introduction - Kansas-Nebraska Act: Primary Documents in American History - Текст электронный // Research Guides at Library of Congress [сайт].- URL: https://guides.loc.gov/kansas-nebraska-act (дата обращения: 7.06.2021).

8. Dred Scott v. Sandford. - Текст: электронный // Wikisource, the free online library: [сайт]. - URL: https://en.wikisource.org/wiki/Dred_Scott_v._Sandford (дата обращения: 7.06.2021).

9. Introduction - Dred Scott v. Sandford: Primary Documents in American History - Текст электронный // Research Guides at Library of Congress [сайт]. - URL: https://guides.loc.gov/dred-scott (дата обращения: 7.06.2021).

10. Куропятник Г.П. Гражданская война в Северной Америке. 1861-1865 / Ин-т всеобщ, истории РАН. - Москва: Наука, 2009. - 354 с.

11. Маркс К., Энгельс Ф. Гражданская война в Северной Америке. Лондон, 7 ноября 1861 года // Собрание сочинений. - 2-е изд. - Москва, 1959. Т. 15. - С. 365-375.

12. Texas v. White et al. - Текст: электронный // LII/Legal Information Institute: [сайт]. URL: https://www.law.cornell.edu/supremecourt/text/74/700 (дата обращения: 7.06.2021) 


\section{References}

1. Slyozkin L. YU. Soglashenie na «Mejflauere». - Tekst: elektronnyj // VIVOS VOCO! ZOVU ZHIVYH!: [sajt]. - URL: http://vivovoco.astronet.ru/vv/papers/ history/flower.htm(data obrashcheniya: 7.06.2021).

2. Introduction - Articles of Confederation: Primary Documents in American History - Tekst elektronnyj // Research Guides at Library of Congress [sajt]. - URL: https://guides.loc.gov/articles-of-confederation (data obrashcheniya: 7.06.2021).

3. Finkel'man P. Kak amerikanskij zakon i Konstituciya SSHA opredelyali rabstvo / per. s angl. K. Sarychevoj; pod red. N. Poselyagina // Novoe literaturnoe obozrenie. - 2016. Vyp. 6. - S. 213-248

4. US Constitution - Full Constitution of The United States [sajt] - URL: https://constitutionus.com (data obrashcheniya: 7.06.2021).

5. Isaev S. A. Missurijskij kompromiss, 1819-1821 // Amerikanskij ezhegodnik. - 2007. Vyp. 2005. - S. 72-89.

6. Nechaj S. L. Prezident Monro i spory o rabstve v kongresse SSHA v 1819-1821 go-dah // Vseobshchaya istoriya: sovremennye issledovaniya: sb. nauch. tr. - Bryansk, 2013. S. 74-88.

7. Introduction - Kansas-Nebraska Act: Primary Documents in American History - Tekst elektronnyj // Research Guides at Library of Congress [sajt]. - URL: https://guides.loc.gov/kansas-nebraska-act (data obrashcheniya: 7.06.2021).

8. Dred Scott v. Sandford. - Tekst: elektronnyj // Wikisource, the free online library: [sajt]. URL: https://en.wikisource.org/wiki/Dred_Scott_v._Sandford (data obrashcheniya: 7.06.2021).

9. Introduction - Dred Scott v. Sandford: Primary Documents in American History - Tekst elektronnyj // Research Guides at Library of Congress [sajt]. - URL: https://guides.loc.gov/dred-scott (data obrashcheniya: 7.06.2021).

10. Kuropyatnik G. P. Grazhdanskaya vojna v Severnoj Amerike. 1861-1865 - In-t vseobshch, istorii RAN. - Moskva: Nauka, 2009. - 354 s.

11. Marks K., Engel's F. Grazhdanskaya vojna v Severnoj Amerike. London, 7 noyabrya 1861 goda // Sobranie sochinenij. - 2-e izd. - Moskva, 1959. T. 15. - S. 365-375.

12. Texas v. White et al. - Tekst: elektronnyj // LII/Legal Information Institute: [sajt]. - URL: https://www.law.cornell.edu/supremecourt/text/74/700 (data obrashcheniya: 7.06.2021).

(C) А.П. Живец, 2021

(C) С.Г. Верещагин, 2021

Для цитирования: Живец А.П., Верещагин С.Г. Федерализм и собственность (на примере американского федерализма) // Территория новых возможностей. Вестник Владивостокского государственного университета экономики и сервиса. - 2021. - Т. 13, № 3. - C. 117-131.

For citation: Zhivets A. P., Vereshchagin S. G. Federalism and property (on the example of American federalism), The Territory of New Opportunities. The Herald of Vladivostok State University of Economics and Service, 2021, Vol. 13, № 3, pp. 117-131.

DOI https://doi.org/10.24866/VVSU/2073-3984/2021-3/117-131

Дата поступления: 15.06.2021. 